\title{
Før tiden var moden - kommentar til Niels Ole Finnemanns artikel
}

\section{Af Anette Dina Sørensen}

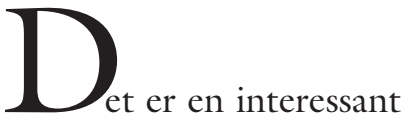

opgave Niels Ole Finnemann stillede sig for 12 år siden - set med nutidens øjne. Vanskeligere er det at fastslå, hvorvidt det også var interessant at undersøge forbindelserne mellem mandlig kønsidentitetsdannelse og former for mandlig teknologifascination, sådan som Finnemann forsøger det i sin artikel fra 1986. Hvad der imidlertid godt kan fastslås er, at opgaven ikke lykkedes særlig godt for Finnemann - set med nutidens øjne. Sådanne konstateringer, lavet i bagklogskabens lys, virker altid bedrevidende og irriterende uangribelige, ikke desto mindre er nærværende kommentars kritikpunkter muliggjorte af de forandringsprocesser og nyskabelser, der er tilflydt verden i de sidste 12 år. Her tænker jeg særligt på udviklingen af informationsteknologien, genteknologi og opdyrkningen af kønsforskningsfeltet og mandeforskningen specielt i USA og England. En genlæsning af Finnemanns artikel tydeliggører forandrin- 
gerne samt de barriere der på daværende tidspunkt var for en mere udfoldet og stringent analyse af mandlighed og teknologi.

Artiklen bærer gennemgående præg af, at der ikke var udviklet noget egentligt begrebsapparat endsige nogen teoretisk ramme for forståelsen af maskulinitet i 1986. Kvindeforskningen, som var godt igang, havde af velkendte grunde endnu ikke inddraget et maskulinitetsperspektiv, og forholdet mellem kønnene - som det udspillede sig på den samfundsmæssige scene havde endnu ikke nødvendiggjort studier i mandlig identitetsdannelse, maskulinitetskonstruktioner osv. Indenfor forskningen var det kvindernes historie, der skulle skrives, kvinders livsvilkår, der skulle blotlægges og kvindelighedens konstruktion, der skulle undersøges. På det kønspolitiske område var det kvinderne, der skulle uddannes, i arbejde, have lederstillinger - kort sagt emanciperes. Årtusinders kvindeundertrykkelse bragte legitimitet til denne prioritering. Måske kan man på den baggrund sige, at Finnemann var foran sin tid, når han skrev om sammenhængen mellem mandlig identitetsdannelse og mandlig teknologifascination. Han foregreb spørgsmål, som først blev aktuelle $5-6$ år senere. Omvendt var han måske bagud for sin tid. Han ekspliciterer ikke motivbaggrunden for artiklens problemfelt, siger kun, at 1970 ernes kritik af det rationelt-saglige mandlighedsideal, der lå bag vækst- og velfærdstænkningen og dermed bag den teknologiske udvikling, skabte en "manifest" mandlig identitetskrise. Hvis Finnemanns primære sigte var at afdække og forklare den mandlige identitetskrises historiske forudsætninger på baggrund af en analyse af teknologiudviklingen som område for mandlig identitetsdannelse, var det vel i 1986 en anelse forsinket!?

Finnemanns artikel er struktureret omkring gennemgangen af tre former for mandlig teknologifascination. Den "klassiske" fascination, den "moderne" fascination og den "postmoderne" fascination.
Hans empiriske grundlag er primært litterære værker af så fremtrædende herrer som H. C. Andersen, Pontoppidan, Johs. V. Jensen, Martin A. Hansen og Bjørnvig. Hans pointer omkring mandlighedskonstruktionen har substans og giver mening, når det drejer sig om den første fascinationsform - den han kalder den "klassiske". Den er tidsmæssigt virksom i begyndelsen af dette århundrede, hævder han, og defineres bl.a af Johs. V. Jensen idé om "maskinen og teknikken som udtryk for den mandlige naturs skaberkraft, kvinden som den omgivende natur - forudsætningen for mandens kraftudfoldelse". Med den efterfølgende gennemgang af den moderne og den postmoderne fascinationsform viser konsekvenserne af den endnu ikke udviklede maskulitetsteoretiske forståelsesramme sig imidlertid. Finnemann mister så at sige sit pejlemærke og derfor sin orienteringssans. Han bruger de analytiske redskaber, der var til rådighed på daværende tidspunkt og de teoretiske diskussioner, som var i vælten dvs. kritikken af subjektfilosofien, den erkendelsesteoretiske skepsis og psykoanalysen. "Hvor blev mændene af?", spørger man uvægerlig sig selv, når man i teksten står tilbage med Ødipalkonflikter og objektiverede eller selvkopierende subjekter, men ingen konkrete bud på de to andre fascinationsformernes mandlighedskonstruktioner. Mandlighedsforståelsen forsvinder som sand mellem fingrene på Finnemann - idag har vi forudsætningerne for at se hvorfor.

Når alt dette er sagt, kan det ikke understreges nok, at Finnemann, trods mangel på analytiske redskaber, havde fat i den lange ende, når han forfægtede den tætte sammenhæng mellem mandlig identitetdannelse og teknologifascination. Idag er der mulighed for en langt større konkretisering af denne sammenhæng. Den amerikanske sociolog, Michael Kimmel har i sin bog "Manhood in America" fra 1996 (10 år senere end Finnemanns artikel) beskrevet, hvorledes den amerikanske "nationbuilding" og industrielle udvikling var tæet sam- 
menvævet med en helt ny maskulinitetsform kaldet "the Self-Made Man". The SelfMade Man var bl.a et opgør med den maskulinitetsform, som var rodfæstet blandt den amerikanske jordbesidderklasse, disse mænd, der aldrig havde været nødt til at knokle sig til økonomisk uafhængighed, fordi de havde fået velstand $\mathrm{og}$ position $\mathrm{i}$ vuggegave, blev med industrialiseringen genstand for ringeagt. Kimmel beskriver, hvordan de blev latterliggjort i skønlitterære bøger, avisartikler og på teatret i begyndelsen af 1800-tallet. Deres moral, livsformer og påklædning blev udskreget som "feminine" sammenlignet med den livsform og moral, som mænd, der havde arbejdet sig op fra bunden, kunne mønstre. For the Self-Made Man var mandligheden skabt af dét hårde slid ved maskinerne, der på sigt førte til den "selvgjorte" succes. Den svenske etnolog, Christer Eldh har gennem flere år lavet feltstudier af hvilken betydning produktionsomlægninger og rationaliseringer har for mandlige maskinarbejdere. Selvom hans empiri både er svensk og nutidig, ser man også i hans undersøgelse, hvordan maskinerne, teknikken bliver identitetsskabende for de mænd, som betjener dem år efter år. Eldh påpeger i artiklen "En otidsenlig kropp" fra 1996, hvilke kønsidentitetskriser mændene kommer ud i, når de som følge af krav om fleksibilitet flyttes fra en maskinel funktion til en ny og for dem ukendt.

Det kunne være interessant, hvis Finnemann opdaterede sin artikel. I retrospekt evaluerede sine hidtidige antagelser, den verden de dengang blev fremsat i, og de profetier og appeller han formulerede dengang i 1986. Desværre virker det som om, et forskningsfelt som "teknologiudviklingens maskulinitetskonstruktioner" har vanskelige kår i disse år. Der bedrives meget lidt forskning, som opererer med problemstillinger, der ligger indenfor dette felt. De skandinaviske mandeforskere beklager selv den bemærkelsesværdige mangel på interesse for at udforske dette område. Svenske Ulf Mellström er én af de fă, der med sin afhandling "Mænd og teknologi" fra 1995 har forsøgt at afdække området. Måske er det for oplagt, for evident, at der er en sammenhæng mellem mandlig identitetsdannelse og den teknologiske udvikling. Så oplagt, at det ikke ansporer til nysgerrighed og undren - hos nogen. Nærværende kommentar skal derfor mest af alt ses som en opfordring til at give netop dette studie mere opmærksomhed i fremtiden. Men hvorfor nu det, hvis ingen rigtig gider trækkes med det? Fordi teknologi ikke længere er noget man kan vælge at ignorere. Informationsteknologien er trængt ind i hjertet af privatsfæren, hvor den anvendes af alle familiens medlemmer, børn som voksne og hvor tidsforbruget foran tastaturet er i eksplosionsagtig stigning. Det er uomgængeligt, at der indenfor ganske få år bliver behov for analyser af, hvad denne "teknologiinvasion" betyder for familiesamlivets karakter, eller hvad den betyder for de gammelkendte relationer i familien? Hvad angår det, der ligger os på sinde her, nemlig køn og teknologi, så står det klart, at kvinders stigende brug af informationsteknologi og deltagelse i udviklingen af foster- og genteknologi udfordrer forestillingen om, at den teknologiske udvikling primært har betydning for den mandlige kønsidentitetsdannelse. En analyse må idag operere med et kønsaspekt, der indbefatter både mænd og kvinder, hvis den skal være tidssvarende.
Anette Dina Sørensen
ph.d.-stipendiat
Roskilde Universitetscenter 